\title{
Acknowledgments
}

The origins of this work go back to the 1980s, when I first detected many of the phenomena I describe here. Since then I have been fortunate to find great support so I could make my scholarly contribution to Ronald Reagan historiography. I owe sincere thanks to many. Special mention goes to Jim Watkins and Frances Williams who, many years ago, opened my eyes to the wonders of history. I owe tremendous gratitude to the staff at Northern Illinois University Press, especially Sara Hoerdeman and Susan Bean. Their enthusiasm and support for this project were both personal and professional. I also thank my anonymous readers for taking a serious look at my work and for their comments, which only strengthened this book. At Mississippi State University-Meridian, Michael Dawkins, Jarrod Fogarty, Renee Gough, James Kelley, Dennis Mitchell, Melanie Thomas, and Jack Tucci all provided friendship and support. The staff at the Ronald Reagan Presidential Library could not have been more helpful, especially Michael Duggan and Steve Branch. I thank my many conference commentators who, in places like Minneapolis, San Diego, Newcastle, Australia, and Oxford, England, offered valuable encouragement and comments. I certainly must thank Shauna Rynn Waters, who read an early version of the manuscript and proved invaluable in her edits and comments.

Gratitude is owed my longtime friends Dennis Bradford, Henry "Duke" Eidt, L.T. Gathing, Andy Harper, Matt Johnson, Tommy King, Jesse Kirkegaard, Emily Machen, Brian C. Miller, Amanda Myers, Tim Overton, Greg Taylor, Michael Upton, and Jeff Walker. At my alma mater, the University of Mississippi, I must first thank Jeffrey R. Watt, who as graduate advisor took a chance on an older nontraditional student. Also at Ole Miss, I thank Charles Eagles, Chiarella Esposito, Robert Haws, Royce Kurtz, Ted Ownby, Sheila Skemp, Douglass Sullivan-González, and Stan Whitehorn. A particular nod goes to the late Winthrop Jordan, who took a special interest in my work. I must also thank John R. Neff, who first 
introduced me to the relationship between history and memory. In every conceivable way, John is the personification of a true friend. Last only because I want him to stand out, I thank Michael V. Namorato. For over thirty years, professionally and personally, he has influenced so many at the University of Mississippi. I am honored and humbled to have been one of his students. In so many ways, he teaches me still.

I thank my grandfather Joseph A. Montgomery, ninety years old at the time of this writing. A World War II submariner and a forty-year veteran of America's railroads, he teaches in just a few quiet words what it takes others hours to say. He is, beyond doubt, one of the last true southern gentlemen. I am today who I am, in large part, because of who he is, because of what he did, and because of what he continues to do. Much gratitude is owed my parents, Jerry and Judy, as well as my brothers, Wayne, Terry, and Todd. Wayne was not with us long. I hope I have honored his memory by approaching each day with the wide-eyed excitement, cheerfulness, and courage he displayed during his short time with us. My father also did not live to see the completion of this project. I can only hope that I brought to this book the tireless work ethic and honesty of purpose that he displayed his entire life. Finally, I want to thank my students, past, present, and future. Every single one of you makes me a better teacher and scholar. 


\section{The Reagan Rhetoric}


